\title{
ISOLASI DAN KARAKTERISASI PENYEBAB PENYAKIT BUSUK BUAH PADA TANAMAN NANAS (Ananas comosus [L.] Merr.)
}

\author{
Tiya Oviana, Titik Nur Aeny \& Joko Prasetyo
}

\author{
Jurusan Agroteknologi, Fakultas Pertanian, Universitas Lampung \\ Jln. Prof. Soemantri Brodjonegoro, No. 1, Bandar Lampung 35145 \\ E-mail: tiyaovi@yahoo.co.id
}

\begin{abstract}
ABSTRAK
Nanas (Ananas comosus L. Merr.) merupakan salah satu komoditas hortikultura yang mendominasi perdagangan buah tropika dunia. Indonesia merupakan negara yang menempati posisi ketiga sebagai negara penghasil nanas olahan dan segar setelah Thailand dan Filipina. Salah satu kendala dalam peningkatan produksi nanas adalah adanya penyakit busuk buah (fruit collapse) yang disebabkan oleh bakteri patogen. Penelitian ini bertujuan untuk mengisolasi penyebab penyakit busuk buah nanas dari perkebunan PT Nusantara Tropical Farm (NTF) dan mengetahui identitas patogen tersebut. Pelaksanaan penelitian ini terdiri dari dua tahap, yaitu tahap pertama berupa isolasi dari jaringan buah dan crown nanas yang sakit untuk mendapat isolat-isolat murni. Tahap kedua adalah karakterisasi yang dilakukan melalui uji morfologi,biokimia, dan patogenisitas untuk mengetahui karakteristik isolat patogen yang diperoleh. Dari hasil isolasi diketahui bahwa penyebab penyakit busuk buah nanas yang ada di PT NTF adalah bakteri. Isolat bakteri tersebut merupakan bakteri Gram negatif, bersifat soft rot, anaerob fakultatif dan virulen. Gejala penyakit antara lain berupa busuk buah, pada daun terbentuk garis-garis berwarna coklat dan melepuh. Berdasarkan gejala yang khas pada daun tanaman sakit serta hasil karakterisasi isolat bakteri, diduga bahwa penyebab penyakit busuk buah pada tanaman nanas di perkebunan PT NTF adalah bakteri Erwinia chrysanthemi.
\end{abstract}

Kata kunci: Erwinia chrysanthemi, fruit collapse, isolasi, karakterisasi bakteri, penyakit busuk buah nanas.

\section{PENDAHULUAN}

Nanas (Ananas comosus L. Merr.) merupakan salah satu komoditas hortikultura yang sangat potensial untuk dikembangkan karena sangat mendominasi perdagangan buah tropika dunia. Produksi nanas di seluruh dunia mencapai $20 \%$ dari produksi buah tropika dunia. Indonesia merupakan negara yang menempati posisi ketiga sebagai negara penghasil nanas olahan dan segar setelah Thailand dan Filipina (Tim Karya Tani Mandiri, 2010). Berdasarkan data produksi nanas tahun 2011 (Pusat Data dan Sistem Informasi Pertanian, 2013), terdapat lima provinsi sebagai sentra produksi nanas di Indonesia, yaitu Lampung (dengan kontribusi 32,80\% terhadap produksi nanas nasional), Jawa Barat $(20,45 \%)$, Sumatera Utara $(11,89 \%)$, Riau $(7,10 \%)$ dan Jawa Tengah $(6,03 \%)$. Dari data sebaran produksi nanas di lima kabupaten di Provinsi Lampung pada tahun 2011, kabupaten dengan produksi nanas terbesar adalah Kabupaten Lampung Tengah dengan produksi 50.420 ton atau $99,78 \%$ dari total produksi nanas Provinsi Lampung. Kabupaten penghasil nanas terbesar lainnya adalah Lampung Barat dengan 29 ton $(0,06 \%)$ dan Kabupaten Lampung Selatan dengan 19 ton $(0,04 \%$ dari total produksi nanas Provinsi Lampung).
Buah nanas banyak dikonsumsi karena mengandung berbagai vitamin seperti vitamin B1, B2, B3, B5, B6 dan vitamin C. Buah nanas dapat dikonsumsi langsung ataupun dalam bentuk lain seperti cocktail, jus, dan selai. Menurut Sunarjono (2000) daun nanas dapat diolah menjadi serat (benang) sebagai bahan baku pakaian, buah nanas mengandung enzim bromelain yang bersifat memecah protein sehingga digunakan sebagai pelunak daging dan kulit nanas dapat digunakan sebagai bahan pakan ternak dan pupuk organik. Di dalam usaha peningkatan produksi nanas, masih ditemukan berbagai kendala, antara lain adalah serangan organisme pengganggu tanaman (OPT) khususnya patogen atau organisme penyebab penyakit. Salah satu penyakit berbahaya pada tanaman nanas di berbagai negara yaitu penyakit busuk buah yang disebabkan oleh bakteri (Sunarjono, 2000).

Gejala penyakit pada buah berupa pembusukan, permukaan kulit buah mengeluarkan banyak cairan dan pada bagian tertentu dari permukaan kulit buah keluar gelembung gas. Adanya penyakit busuk buah nanas yang disebabkan oleh bakteri dikhawatirkan dapat menurunkan kualitas buah. Selain itu bakteri tidak hanya menginfeksi buah tetapi juga menginfeksi crown nanas sehingga berpengaruh terhadap ketersediaan bibit nanas. 
Apabila penyakit berkembang dalam skala luas, petani maupun perusahaan penghasil nanas akan mengalami kerugian yang besar.

Di Malaysia sejak tahun 1972 penyakit busuk buah nanas disebabkan oleh Erwinia chrysanthemi (Semangun, 2007). Pada Desember tahun 2003, E. chrysanthemi juga ditemukan menginfeksi tanaman nanas di Hawai sedangkan di Espirito Santo, Brazil penyakit busuk buah pada tanaman nanas disebabkan oleh bakteri Klebsiella sp. yang berasosiasi dengan tiga jenis ragi yaitu Candida sp., Saccharomyces sp., dan Kloeckera sp. (Korres dkk., 2010). Penyakit busuk buah bakteri ternyata juga ditemukan pada nanas yang ditanam di areal perkebunan PT Nusantara Tropical Farm (NTF) yang terletak di Kabupaten Lampung Timur Provinsi Lampung. Penyakit tersebut menunjukkan gejala berupa buah yang mengalami busuk basah dan pada bagian yang busuk tersebut mengeluarkan bau tidak sedap (anyir). Daging buah yang terinfeksi menjadi lunak dan mengeluarkan banyak cairan (eksudat) yang disertai dengan gelembung udara. Penyakit dengan gejala seperti itu belum pernah dilaporkan keberadaannya di daerah-daerah penghasil nanas sehingga belum diketahui penyebabnya. Oleh karena itu penelitian ini bertujuan untuk mengkarakterisasi penyebab penyakit busuk buah pada tanaman nanas di perkebunan PT Nusantara Tropical Farm (NTF).

\section{BAHAN DAN METODE}

Penelitian ini dilaksanakan pada bulan Juli sampai dengan Desember 2014. Isolasi dan karakterisasi penyebab penyakit dilakukan di Laboratorium Penyakit Tanaman, Jurusan Agroteknologi Bidang Proteksi Tanaman, Fakultas Pertanian Universitas Lampung. Pengambilan sampel tanaman sakit dilakukan di perkebunan PT Nusantara Tropical Farm.

Alat-alat yang digunakan dalam penelitian ini adalah cawan petri, autoklaf, gelas preparat, erlenmeyer, tusuk gigi, gelas ukur, tabung reaksi, jarum ose, timbangan digital, bunsen, mikropipet, rotamixer, Laminar Air Flow Hood, kertas label, alumunium foil dan alat tulis. Bahanbahan yang digunakan dalam penelitian ini adalah aquades, media Potato Dextrose Agar (PDA), Nutrient Agar (NA), yeast extract peptone dextrose agar (YPD), Tetrazolium Chlorida (TZC), media OksidatifFermentatif , minyak parafin, gliserol, $\mathrm{MnCl}_{2} \cdot 4 \mathrm{H}_{2} \mathrm{O}$, $\mathrm{KOH} 3 \%$, kristal violet, yodium, safranin, alkohol, air steril, buah atau crown nanas yang sehat, umbi kentang dan buah serta crown nanas yang mengalami penyakit busuk buah. Tahap pertama penelitian ini berupa isolasi bakteri dari jaringan buah atau crown nanas yang sakit untuk mendapat isolat-isolat murni. Bagian buah dan crown yang sakit dipotong kecil berukuran $2 \times 2 \mathrm{~mm}$ sebanyak \pm 10 potongan. Selanjutnya, potongan tersebut dimasukkan ke dalam tabung reaksi, ditambah $5 \mathrm{cc}$ air steril, lalu ditutup menggunakan alumunium foil, dan dihomogenkan menggunakan rotamixer selama beberapa menit. Hasil suspensi tersebut selanjutnya digoreskan pada media PDA dan NA menggunakan jarum ose, dan diinkubasikan pada suhu ruang selama 24-48 jam. Beberapa koloni yang tumbuh direisolasi menggunakan media yang sama tetapi dengan metode penggoresan kuadran. Tahap kedua penelitian ini adalah melakukan beberapa pengujian, antara lain:

Uji gram menggunakan $\mathrm{KOH} 3 \%$ untuk mengetahui bakteri yang dibiakkan termasuk dalam kategori gram positif atau gram negatif dengan mengambil 1-2 ose bakteri dan meletakkannya di atas gelas preparat kemudian ditetesi $\mathrm{KOH} \mathrm{3 \%}$ sebanyak 12 tetes dan dicampur-ratakan. Setelah itu, tusuk gigi steril ditempelkan pada campuran tersebut dan diangkat secara perlahan. Apabila terbentuk benang lendir yang tidak terputus, maka bakteri yang dibiakkan merupakan bakteri gram negatif, namun apabila tidak terbentuk, maka bakteri tersebut termasuk bakteri gram positif (Ryu, 1938 dalam Suslow dkk., 1982). Untuk meyakinkan hasil uji ini maka dilakukan uji gram dengan teknik pewarnaan dengan meletakkan isolat bakteri menggunakan jarum ose pada gelas preparat, kemudian diberi larutan kristal violet, yodium, alkohol dan safranin secara bergantian. Pengamatan dilakukan dengan menggunakan mikroskop, bakteri Gram positif akan nampak berwarna ungu, sedangkan Gram negatif berwarna merah (Cappuccino dan Sherman, 1983 dalam Purwohadisantoso dkk., 2009).

Uji dengan media TZC dilakukan untuk melihat pertumbuhan bakteri baik yang virulen maupun avirulen dengan membuat suspensi dari 1 ose bakteri yang dimasukkan ke dalam $5 \mathrm{ml}$ air steril dan diencerkan sampai pengenceran $10^{-8}$, kemudian sebanyak 10 il suspensi bakteri ditebar ke media TZC dan diinkubasi pada suhu $28^{\circ} \mathrm{C}$ selama minimal 48 jam dan diamati bentuk koloninya (Kaneshiro dkk., 2008). Bakteri yang virulen koloninya berwarna putih dengan pusat/bagian tengahnya berwarna merah. Sebaliknya, bakteri yang avirulen memiliki ciri koloni tidak berlendir, berwarna merah (Gunawan, 2006).

Pada uji pembusukan umbi kentang, masingmasing isolat bakteri digoreskan menggunakan jarum ose pada bagian tengah umbi kentang yang telah dicuci di air mengalir selama 35 menit. Selanjutnya kentang tersebut diletakkan dalam cawan petri, kemudian diberi air steril sebanyak $1 \mathrm{ml}$ dan diinkubasi selama 2-3 hari. 
Reaksi positif ditunjukkan dengan terjadinya pembusukan pada bagian tengah kentang (Lelliot dan Stead, 1987 dalam Masnilah dkk., 2013). Uji O/F dilakukan untuk mengetahui sifat aerob atau anaerob bakteri. Masingmasing bakteri diinokulasikan pada $5 \mathrm{ml}$ media oksidatiffermentatif sebanyak 2 tabung reaksi untuk setiap isolat. Satu ose bakteri ditusukkan pada masing-masing media tersebut, pada tabung 1 ditutupi dengan minyak parafin sebanyak $1 \mathrm{ml}$, sedangkan pada tabung 2 tidak ditutupi dengan minyak parafin. Setelah diinkubasi selama 714 hari dilakukan pengamatan terhadap perubahan warna media dari hijau menjadi kuning pada masingmasing tabung. Apabila terjadi perubahan warna dari hijau menjadi kuning pada kedua media (dengan atau tanpa parafin), hal ini menunjukkan bahwa bakteri tersebut bersifat oksidatif dan fermentatif. Jika perubahan warna menjadi kuning hanya pada tabung yang diberi minyak parafin maka bakteri tersebut bersifat fermentatif. Sebaliknya jika terjadi perubahan warna kuning hanya pada tabung yang tidak diberi minyak parafin, hal ini menunjukkan bahwa bakteri tersebut bersifat oksidatif (Lelliot dan Stead, 1987 dalam Masnilah dkk., 2013).

Menurut An Lee dan Pin Yu (2006) media NGM merupakan media yang dikembangkan untuk membedakan bakteri E. chrysanthemi penyebab penyakit busuk buah nanas dari Erwinia spp. lainnya berdasarkan produksi pigmen biru Indigoidine. Media ini terdiri dari Nutrient Agar ditambah 1\% Gliserol yang akan menginduksi produksi pigmen dan $2 \mathrm{mM}$ $\mathrm{MnCl}_{2} \cdot 4 \mathrm{H}_{2} \mathrm{O}$ yang akan meningkatkan pengembangan warna. Biakan E. chrysanthemi yang tumbuh pada media NGM dicirikan dengan koloni yang berwarna coklat gelap sampai biru.

Uji patogenisitas dilakukan untuk mengetahui apakah suatu bakteri bersifat patogen atau tidak dengan cara menginokulasikan biakan bakteri tersebut pada tanaman inang yang sehat. Inokulasi dilakukan dengan menyuntikkan suspensi bakteri ke buah nanas yang sehat sebanyak $10 \mathrm{ml}$. Hasil uji patogenisitas dinyatakan positif jika di sekitar area bekas suntikan pada buah nanas ditemukan gejala busuk seperti yang ditemukan pada buah nanas yang mengalami penyakit busuk buah bakteri di lapang sebelumnya.

\section{HASIL DAN PEMBAHASAN}

Dari isolasi yang dilakukan dari jaringan buah yang sakit diperoleh dua isolat bakteri yang masingmasing tampak berbeda, yaitu isolat dengan ciri koloni bakteri berwarna bening /transparan (isolat A) dan isolat yang berwarna putih susu dengan tekstur lendirnya yang pekat dan agak memadat (isolat B) (Gambar 1). Dari sampel tanaman nanas yang lain, berhasil diisolasi bakteri dari jaringan buah sakit. Ciri-ciri isolat tersebut antara lain koloninya berwarna putih (isolat $\mathrm{C}$ ). Dari jaringan crown yang sakit juga diperoleh isolat yang mempunyai ciri yang sama dengan isolat bakteri dari buah yaitu koloninya berwarna putih (isolat D) (Gambar 1).

Hasil uji karakterisasi pada masing-masing isolat bakteri dapat dilihat pada Tabel 1. Hasil uji gram menggunakan $\mathrm{KOH} \mathrm{3 \%}$ menunjukkan bahwa isolat A merupakan kelompok Gram positif (tidak terbentuknya benang lendir), sedangkan isolat B, C dan D merupakan kelompok Gram negatif yang dicirikan dengan terbentuknya benang lendir yang tidak terputus sepanjang kurang lebih $2 \mathrm{~cm}$ (Gambar 2a). Untuk meyakinkan hasil uji ini, maka dilakukanlah uji gram bakteri dengan teknik pewarnaan, apabila hasil uji gram dengan teknik pewarnaan sama dengan hasil uji gram menggunakan $\mathrm{KOH} \mathrm{3 \%}$, maka hasil uji dinyatakan akurat. Hasil uji menunjukkan isolat A berwarna ungu yang berarti bahwa isolat $\mathrm{A}$ merupakan bakteri gram positif. Isolat bakteri $\mathrm{B}, \mathrm{C}$ dan $\mathrm{D}$ menunjukkan hasil

Tabel 1. Hasil uji karakterisasi pada isolat bakteri A, B, C dan D

\begin{tabular}{lcccc}
\hline \multirow{2}{*}{ Pengujian } & \multicolumn{4}{c}{ Hasil Uji } \\
\cline { 2 - 5 } & Isolat A & Isolat B & Isolat C & Isolat D \\
\hline KOH 3\% & Gram positif & Gram negatif & Gram negatif & Gram negatif \\
Pewarnaan Gram & Gram positif & Gram negatif & Gram negatif & Gram negatif \\
Pembusukan & - & + & - & - \\
Umbi Kentang & - & Oksidatif dan & Oksidatif & Oksidatif \\
O/F & - & Fermentatif & & - \\
NGM & - & - & - & Avirulen \\
TZC & - & Virulen & Avirulen & - \\
Patogenisitas & - & + & - & \\
\hline
\end{tabular}



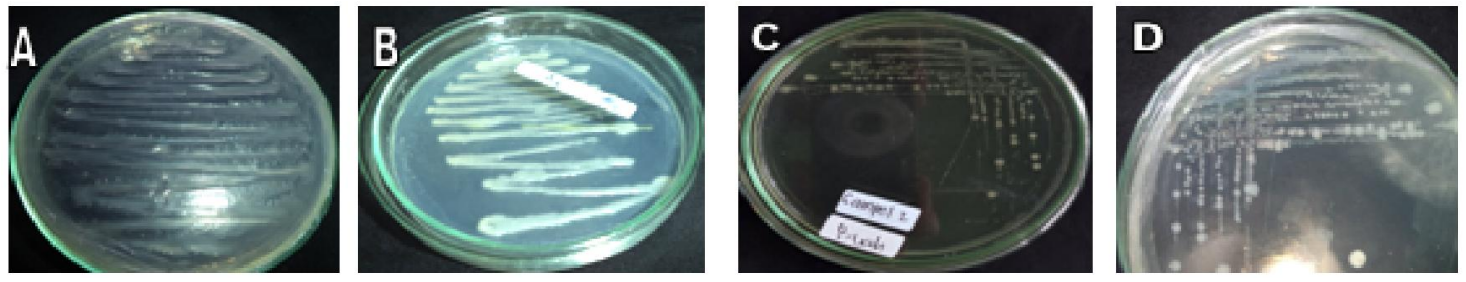

Gambar 1. Isolat bakteri A, B, C dan D
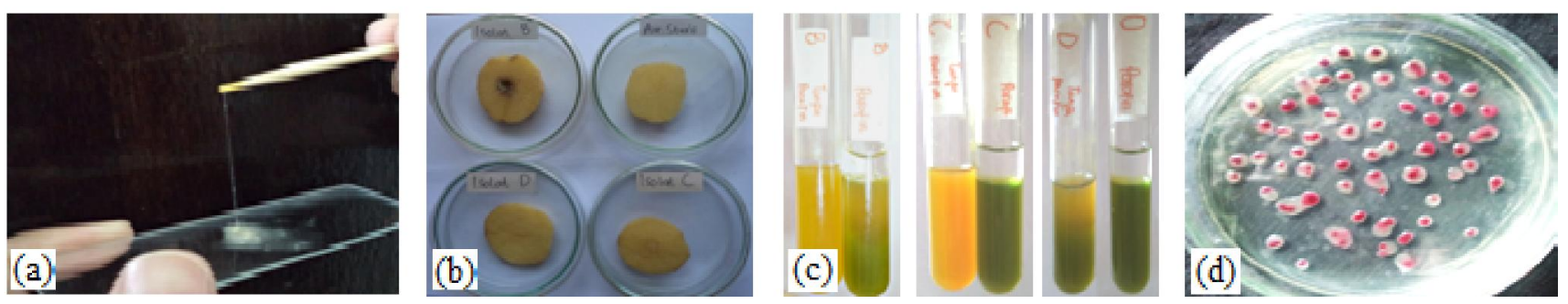

Gambar 2. (a) Hasil uji gram menggunakan $\mathrm{KOH} \mathrm{3 \% ,} \mathrm{(b)} \mathrm{dan} \mathrm{(c)} \mathrm{Hasil} \mathrm{uji} \mathrm{pembusukan} \mathrm{umbi} \mathrm{kentang} \mathrm{(kiri)} \mathrm{dan} \mathrm{uji}$ $\mathrm{O} / \mathrm{F}$ pada isolat bakteri B, C dan D (kanan) Hasil uji menggunakan media TZC pada isolat B, (d) Hasil uji menggunakan media TZC pada isolat B.

bahwa sel-selnya berwarna pink yang berarti ketiga isolat tersebut merupakan bakteri gram negatif.

Uji pembusukan umbi kentang dilakukan terhadap isolat bakteri yang tergolong sebagai Gram negatif. Dari Tabel 1 diketahui hanya isolat $\mathrm{B}$ yang menunjukkan hasil positif, yaitu terjadi pembusukan pada bagian tengah kentang 2 hari setelah digores dengan bakteri. Pada umbi kentang yang tidak digores dengan bakteri (kontrol), digores dengan isolat $\mathrm{C}$ dan $\mathrm{D}$ hasil ujinya dinyatakan negatif, karena tidak terjadi pembusukan (Gambar 2b). Hasil uji oksidatif/fermentatif menunjukkan perubahan warna dari hijau ke kuning pada media terjadi setelah 7 hari. Isolat B menunjukkan hasil positif pada uji oksidatif dan fermentatif. Hal ini ditunjukkan oleh adanya perubahan warna media dari hijau menjadi kuning pada tabung yang tidak ditutupi minyak parafin dan setengah bagian media yang berubah warna menjadi kuning pada tabung yang diberi parafin. Pada isolat $\mathrm{C}$ dan $\mathrm{D}$ perubahan warna kuning hanya pada tabung yang tidak ditutupi parafin, maka bakteri $\mathrm{C}$ dan D bersifat oksidatif (Gambar 2c). Berdasarkan hasil uji pembusukan umbi kentang dan uji $\mathrm{O} / \mathrm{F}$ maka isolat bakteri yang diuji dengan media TZC hanya isolat $\mathrm{B}$. Hasil uji menyatakan isolat B bersifat virulen. Ciri penting yang membedakannya dengan bakteri avirulen adalah koloninya berwarna putih dengan pusat/bagian tengahnya berwarna merah (Gambar 2d).

Media NGM merupakan media yang dikembangkan untuk membedakan bakteri $E$. chrysanthemi dari spesies Erwinia lainnya. Beberapa strain E. chrysanthemi yang tumbuh koloninya berubah warna menjadi coklat gelap atau biru karena adanya pigmen biru Indigoidine. Isolat bakteri B yang ditumbuhkan pada media NGM mempunyai ciri yang tidak berubah, yaitu tetap berwarna putih susu. Tidak adanya perubahan warna pada koloni bakteri dapat disebabkan oleh sifat media NGM yang kurang stabil, yaitu tidak adanya perubahan warna koloni pada beberapa strain dari E. chrysanthemi. Hasil uji patogenisitas menunjukkan bahwa gejala pembusukkan hanya muncul pada buah yang diinokulasi dengan isolat bakteri B. Gejala muncul pada 2 minggu setelah inokulasi. Di daerah bekas injeksi, kulit buah mengalami pembusukan dan berwarna coklat, sedangkan pada buah yang diinokulasikan air steril (kontrol), isolat C dan D tidak mengalami pembusukan .

Berdasarkan ciri-ciri daun bergejala busuk yang ada di perkebunan PT Nusantara Tropical Farm, tanaman nanas tersebut mengalami penyakit busuk buah bakteri yang disebabkan oleh E. chrysanthemi. Menurut Kaneshiro dkk. (2008) penyakit ini memiliki ciri-ciri khusus yaitu adanya gejala busuk basah pada daerah tengah daun di sekitar meristem apikal diikuti dengan pembentukan garis coklat pada helai daun dan di jaringan mesofil yang selanjutnya permukaan daun menjadi melepuh (Gambar 3a). Selain itu, dalam beberapa kasus, buah nanas muda juga terinfeksi bakteri secara laten, buah mengalami busuk lunak secara cepat dan mengalami runtuh pada fase kematangan buah (Gambar 3a). Ciri-ciri khusus ini ditemukan pada 

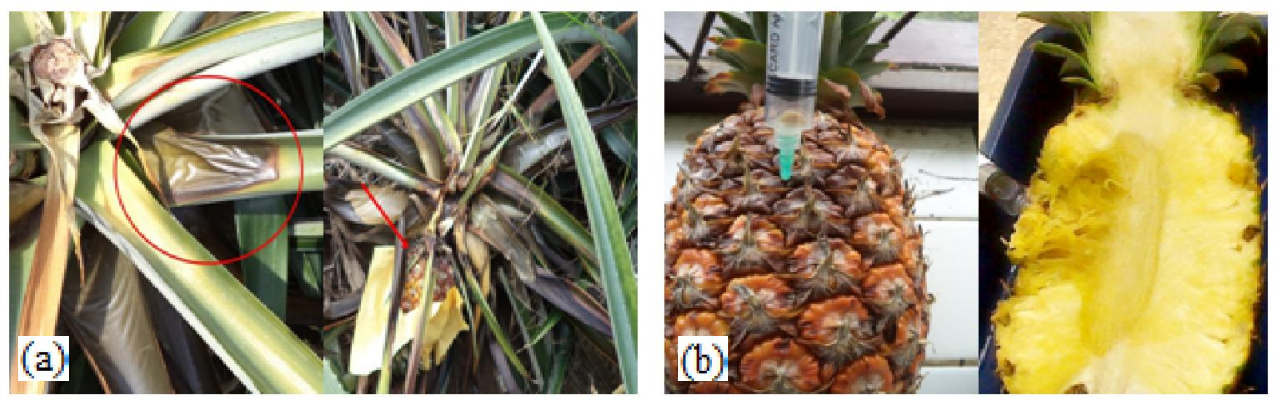

Gambar 3. (a) Gejala penyakit pada daun (kiri) dan nanas penyakit buah saat fase pematangan buah (kanan) di PT Nusantara Tropical Farm dan (b) Gejala pada jaringan buah nanas (kanan) yang telah diinjeksi dengan suspensi bakteri isolat B (kiri).

tanaman nanas yang sakit di perkebunan PT Nusantara Tropical Farm.

Hasil isolasi dari jaringan buah dan crown yang sakit menunjukkan hanya biakan bakteri yang tumbuh pada media PDA dan NA. Biakan bakteri tersebut selanjutnya dikarakterisasi dengan serangkaian uji. Dari hasil dari beberapa uji terhadap salah satu isolat bakteri yang didapat yaitu isolat B yang cocok dengan karakter E. chrysanthemi diantaranya hasil uji $\mathrm{KOH} \mathrm{3 \%}$ menujukkan isolat $\mathrm{B}$ merupakan bakteri gram negatif. Hasil uji ini diperkuat dengan hasil uji gram menggunakan teknik pewarnaan yang menunjukkan hasil akhir positif yaitu sel-sel bakteri tampak berwarna merah jambu.

Dari hasil uji pembusukan umbi kentang, diketahui hanya isolat $B$ yang hasilnya positif, yang berarti bahwa isolat B merupakan bakteri yang bersifat soft rot ditandai dengan membusuknya bagian tengah kentang yang digoreskan bakteri. Bakteri yang bersifat soft rot merupakan kelompok bakteri yang menyebabkan busuk lunak pada tanaman dan bersifat patogenik. E. chrysanthemi merupakan bakteri patogen dari genus Erwinia yang bersifat soft rot (Sahilah dkk., 2008). Uji $\mathrm{O} / \mathrm{F}$ menunjukkan isolat $\mathrm{B}$ positif pada uji oksidatif dan fermentatif, yang berarti bahwa isolat $\mathrm{B}$ bersifat anaerob fakultatif, yaitu bakteri dapat hidup pada kondisi lingkungan oksidatif dan dapat pula hidup pada lingkungan fermentatif. Menurut Kaneshiro dkk. (2008) E. chrysanthemi merupakan bakteri yang tergolong dalam bakteri anaerob fakultatif. Pada uji menggunakan media TZC, diketahui isolat B bersifat virulen yaitu dapat menyebabkan penyakit. Uji selanjutnya merupakan uji menggunakan media NGM, hasil uji menunjukkan tidak adanya perubahan warna pada koloni bakteri. Hal ini disebabkan oleh sifat media NGM yang tidak stabil. Pengujian terhadap beberapa strain dari $E$. chrysanthemi tidak menunjukkan adanya perubahan warna pada koloni bakteri yang ditumbuhkan pada media NGM (Suharjo, Komunikasi Pribadi). Setelah dilakukan serangkaian uji berdasarkan reaksi biokimia sel bakteri, maka uji selanjutnya merupakan uji patogenisitas. Uji ini dilakukan untuk mengetahui kemampuan bakteri yang diinokulasikan dalam menimbulkan gejala pada tanaman yang diuji. Hasil inokulasi isolat $\mathrm{B}$ pada buah nanas sehat yang berumur 2-3 minggu sebelum panen menunjukkan pada permukaan kulit buah di sekitar area bekas suntikan terjadi busuk basah berwarna coklat gelap. Selain itu ketika dibelah daging buah berongga dan berwarna coklat (Gambar 3b).

\section{KESIMPULAN}

Dari hasil penelitian yang telah dilakukan dapat disimpulkan bahwa penyebab penyakit busuk pada buah nanas di perkebunan PT Nusantara Tropical Farm merupakan bakteri Gram negatif, bersifat soft rot, anaerob fakultatif dan virulen. Berdasarkan gejala khas berupa munculnya garis coklat dan lepuhan pada daun tanaman yang sakit serta hasil karakterisasi yang menyatakan bahwa isolat B termasuk Gram negatif, bersifat soft rot, anaerob fakultatif, virulen dan bersifat patogenik, maka diduga bahwa penyebab penyakit busuk buah pada tanaman nanas di perkebunan PT Nusantara Tropical Farm adalah bakteri Erwinia chrysanthemi.

\section{SANWACANA}

Ucapan terima kasih saya sampaikan kepada staff dan karyawan PT Nusantara Tropical Farm yang telah membantu dalam mendapatkan informasi dan bahan penelitian. 


\section{DAFTAR PUSTAKA}

An Lee, Y \& C.P. Yu. 2006. A Differential Medium for the Isolation and Rapid Identification of a Plant Soft Rot Pathogen, Erwinia chrysanthemi. Journal of Microbiological Methods. 64(2): 200-206.

Gunawan, O.S. 2006. Virulensi dan Ras Ralstonia solanacearum pada Pertanaman Kentang di Kecamatan Pangalengan, Kab. Bandung, Jawa Barat. Jurnal Hortikultura. 16(3): 211-218.

Kaneshiro, W.S., M. Burger., B.G. Vine., A.S. de Silva., and A.M. Alvarez. 2008. Characterization of Erwinia chrysanthemi from A Bacterial Heart Rot of Pineapple Outbreak in Hawaii. Plant Disease. 92(10): 1444-1450.

Korres, A.M.N., J.A. Ventura., and P.M.B. Fernandes. 2010. First Report of Bacterium and Yeast Associated with Pineapple Fruit Collapse in Espirito Santo State, Brazil. Plant Disease. 94(12): 1509.

Masnilah, R., A.L. Abadi., T.H. Astono., dan L.Q. Aini. 2013. Karakterisasi Bakteri Penyebab Penyakit Hawar Daun Edamame di Jember. Berkala Ilmiah Pertanian 1(1): 10-14.

Purwohadisantoso, K., E. Zubaidah., dan E. Saparianti. 2009. Isolasi Bakteri Asam Laktat dari Sayur Kubis yang Memiliki Kemampuan Penghambatan Bakteri Patogen (Staphylococcus aureus, Listeria monocytogenes, Escherichia coli, dan Salmonella thypimurium). Jurnal Teknologi Pertanian. 10 (1): 19-27.
Pusat Data dan Sistem Informasi Pertanian. 2013. Informasi komoditas hortikultura. http:// www.deptan.go.id. diakses pada tanggal 8 Januari 2014.

Sahilah, A.M., Rozeita, L., Umi Kalsum, M.S., and Son, R. 2008. Typing of Erwinia chrysanthemi Isolated from Josapine Pineapple in Malaysia Using Antimicrobial Susceptibility, Plasmid Profiles, ERIC-PCR and RFLP Analysis. International Food Research Journal. 15(3): 273-280.

Semangun, H. 2007. Penyakit-penyakit Tanaman Hortikultura di Indonesia. Edisi ke-2. Gadjah Mada University Press. Yogyakarta.

Sunarjono, H. Hendro. 2000. Prospek Berkebun Buah. Penebar Swadaya. Depok.

Suslow, T.V., M.N. Scorth., and M. Isaka. 1982. Application of Rapid Methods for Gram Differentiation of Plant Pathogenic and Saprophytic Bacteria Without Staining. Phytopathology. 72(7): 917 - 918.

Tim Karya Tani Mandiri. 2010. Pedoman Bertanam Buah Nanas. Nuansa Aulia. Bandung. 